\title{
Metáforas en el cine - un recorrido por las representaciones del documental argentino sobre la crisis de 2001
}

\author{
Teresa Álvarez Martín-Nieto*
}

Resumo: Este artigo analisa as metáforas usadas para construir a crise de 2001, do documentário argentino. O ponto de partido é que as metáforas visuais presentes nestas histórias têm uma origem conceitual, através das quais a experiência histórica representada é organizada. Concluiu-se que, nos documentários analisados, as metáforas construem a crise em termos de oposição e em comparação com outros períodos do passado argentino.

Palavras-chave: metáforas; documentários; crise argentina de 2001; linguística cognitiva; teoria integrada de metáfora primária.

Resumen: El presente artículo analiza las metáforas que el cine documental argentino ha utilizado para construir la crisis de 2001. Se parte de la concepción de que las metáforas visuales presentes en estos relatos tienen un origen conceptual, a través del cual se organiza la experiencia histórica representada en ellos. Se concluye que las metáforas presentes en los documentales analizados construyen la crisis en términos de oposición y la comparan con otros periodos del pasado argentino.

Palabras clave: metáforas; cine documental; crisis 2001 argentina; lingüística cognitiva; teoría integrada de la metáfora primaria.

\begin{abstract}
This article analyzes the metaphors Argentine documentary film has been used to build the 2001 crisis, one of the major milestones of the recent past of this country. It starts from the idea that visual metaphors present in these stories have a conceptual origin, through which represented the historical experience is organized. It concludes that the visual metaphor depicting the history.

Keywords: metaphors; documentary; Argentina 2001 crisis; cognitive linguistics; integrated theory of primary metaphor.
\end{abstract}

Résumé: Cet article analyse les métaphores que le documentaire argentin a utilisé pour construire la crise de 2001. Il se fonde sur l'idée que les métaphores visuelles présentes dans ces histoires ont une origine conceptuelle, à travers laquelle l'expérience historique représentée les organise. On peut en déduire que les métaphores documentaires ont analysé la crise construite en termes d'opposition en la comparant à d'autres périodes du passé argentin.

Mots-clés : métaphores ; documentaires ; crise argentine 2001 ; linguistique cognitive ; théorie intégrée ; métaphore primaire.

* Universidad Complutense de Madrid. Facultad de Geografía e Historia. Departamento: Instituto de Investigación Universitaria Ortega y Gasset 28040, Madrid, España. E-mail: sieteseptiembre@hotmail.com

Sumisión del artículo: 05 de junio de 2017. Notificación de aceptación: 31 de julio de 2017.

Doc On-line, n. 22, setembro de 2017, www.doc.ubi.pt, pp. 273-294. 


\section{Introducción ${ }^{1}$}

Dirijamos la mirada hacia los dos primeros planos (imágenes 1 y 2) que aparecen en el documental Memorias del saqueo (Fernando Solanas, 2004). En el primer caso la pantalla nos devuelve un travelling contrapicado de dos rascacielos. El plano yuxtapuesto, en el que se utiliza un ángulo picado, nos muestra a una niña descalza que come en el suelo, figura sobre la cual la cámara, que tiembla al hombro de un operador, aplica un zoom lento.
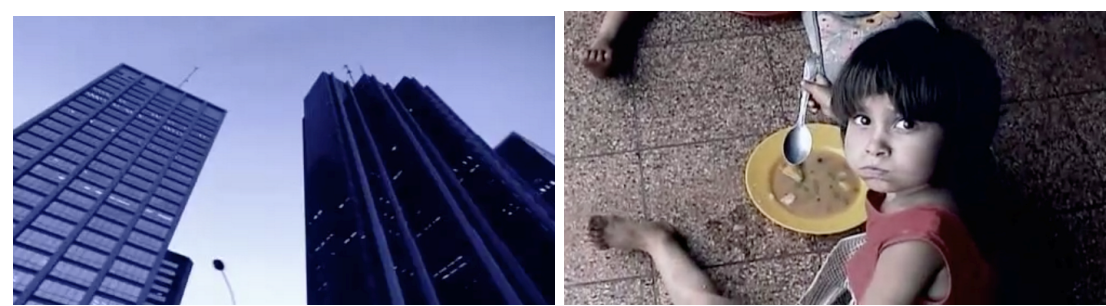

Imágenes 1 y 2.

Esta breve descripción introduce el tema que vamos a abordar en las siguientes páginas: las metáforas que el cine documental argentino ha utilizado para representar la crisis de 2001 y cómo estas han organizado dicha experiencia histórica. ${ }^{2}$ La selección de las entidades y ángulos que hemos expuesto unas líneas más arriba confirman la presencia de varias metáforas. ${ }^{3}$ De un lado, nos encontramos ante edificios del centro económico y financiero de Buenos Aires, imagen metonímica que evoca a una parte de las instituciones responsables de gestionar las políticas neoliberales que fueron aplicadas en el país a partir de la última dictadura cívico-militar (1976-1983) y profundizadas durante los gobiernos de Carlos Menem (1989-1999) y Fernando de la Rúa (1999-2001); a las que la cámara otorga control y poder a través del uso del

1. Agradezco los comentarios recibidos por parte de Marisa González de Oleaga, que han quedado incluidos en la versión final de este texto.

2. Durante los años 2001 y 2002 Argentina atravesó la peor situación económica y social de su historia, una crisis que se materializó en la quiebra del modelo neoliberal que había gestionado política y económicamente el país durante el cuarto de siglo previo, la pérdida de la confianza de los ciudadanos en las instituciones y, entre otras manifestaciones, el resurgimiento de nuevos actores sociales en la esfera pública.

3. Como veremos más adelante siguiendo los postulados de la Teoría Integrada de la Metáfora Primaria, en estas imágenes observamos la metonimia "El lugar por la institución", a través de los edificios que simbolizan las instituciones que gestionaron las políticas neoliberales; una metáfora ontológica de personificación, en la imagen de la niña que evoca la pobreza creciente en el país; y las metáforas visuales de correlación "Similitud es proximidad", "Control es arriba" y "Estar controlado es abajo", que asocian ambas imágenes y oponen la posición de poder y control de los edificios que simbolizan el sistema neoliberal a la situación de subordinación que vive la niña. 
Metáforas en el cine - un recorrido por las representaciones del documental argentino sobre la crisis de 2001

ángulo contrapicado. De otro, atisbamos la expansión de la pobreza generada en Argentina como consecuencia de la aplicación del citado modelo político y económico, situación que queda personificada en la menor de pocos años que mira sin pestañear a la cámara, la cual subraya su condición vulnerable a través del ángulo picado. Dos planos con los que constatamos el uso de la metáfora como herramienta de construcción de la crisis, pues mediante su yuxtaposición y la oposición de sus contenidos se establecen las causas y consecuencias de esta porción del pasado del país, sus responsables y sus víctimas.

La presencia de este tipo de metáforas es notable en los documentales argentinos que abordan la crisis de 2001. Pero, como acabamos de ver, sus usos y funciones van más allá del mero adorno con el que dotar a estos relatos de dinamismo visual, de su dimensión estética. Por el contrario, las metáforas impregnan el relato documental, organizan el pasado que proyectan las imágenes y, a través de ellas, condicionan los pensamientos y acciones de los receptores. Una presencia, como aquí se defiende, que consolida la condición del cine como medio legítimo de representación del pasado. Pero antes de pasar a analizar las metáforas que construyen la crisis de 2001 en el cine documental abordemos algunos aspectos que, inexorablemente, van unidos a ella.

En primer lugar, el interés interdisciplinario que se ha desarrollado en torno a este dispositivo, en cuya evolución se pueden destacar varios hitos históricos. El primero de ellos se ubica, cronológicamente, en el siglo IV a. C. y ha quedado personificado en la figura de Aristóteles, que ya en sus obras Poética y Retórica concebía la metáfora como un desplazamiento (en Ricoeur, 2007: 23). El segundo momento histórico clave se produce en los siglos XVIII y XIX, cuando comienza a desarrollarse su dimensión cognitiva, dejando de lado su carácter puramente estético. El tercer hito tiene lugar ya entrado el siglo XX, años en los que la lingüística realiza las principales aportaciones en torno a la metáfora, como las investigaciones de Searle, Grice y Sperber y Wilson (en Escandell Vidal, 2006, 196-200), buscando esta última desarrollar una teoría conceptual en torno a tal figura. Su aparición ha de esperar hasta 1980, con la publicación de Metáforas de la vida cotidiana, de George Lakoff y Mark Johnson, trabajo en el que los autores defienden que la metáfora tiene un origen conceptual a partir del cual se organiza el conocimiento. Esta propuesta ha sido objeto de modificaciones a lo largo de las últimas tres décadas, motivo por el cual sus autores propusieron aunar estos avances en la Teoría Integrada de la Metáfora Primaria, que queda incluida en su obra de 1996 Philosophy in the flesh. The embodied mind and its Challenge to western thought. ${ }^{4}$

4. Constituida, entre otras, por la Teoría Conceptual de la Metáfora y su perfeccionamiento en la Teoría de la Integración Conceptual, la Teoría de la Metáfora Primaria, la Teoría Neuronal y la Teoría de la Combinación. 
La extensión de los estudios en torno a la dimensión conceptual permite contemplar, en segundo lugar, la posibilidad de aplicar las teorías de la lingüística cognitiva a la metáfora visual. Este dispositivo, a lo largo del siglo XX, ha sido objeto de análisis de diferentes teóricos del campo audiovisual, especialmente del cine. Tales reflexiones se han centrado en confirmar la presencia de la metáfora visual en tales relatos, que se configura a través de distintos procedimientos de la realización audiovisual, como la puesta en escena, el montaje o el encuadre. Sin embargo, son pocas las propuestas académicas que analizan la dimensión conceptual de la metáfora en materiales audiovisuales, a excepción de las investigaciones de María Jesús Ortiz Díaz-Guerra. ${ }^{5}$

Por último, no podemos dejar de inscribir la metáfora en el debate sobre el relato histórico. A lo largo del siglo XX, y fundamentalmente en sus últimas dos décadas, se incrementó la preocupación sobre la incidencia del lenguaje y de la narrativa en los trabajos sobre el pasado. En este sentido, uno de los principales exponentes de la historiografía post-moderna, Hayden White, sostiene que el relato sobre el pasado es una construcción que el historiador impone a los hechos, fabricación que se materializa a través del discurso que este aplica, ya que todo texto histórico recibe información de un tropo, que puede ser una metáfora, una metonimia, una sinécdoque o una ironía. White justifica este procedimiento en que el historiador debe dotar de significado los datos que maneja, hacer comprensibles los hechos pasados a una audiencia determinada. Una tarea para la que se vale del uso del lenguaje figurativo (White, 2003: 163). Asimismo, entre los historiadores que defienden la presencia de la metáfora en el relato histórico destaca Frank Ankersmit, quien señala que esta se configura como un instrumento lingüístico a través del cual podemos organizar el conocimiento del mundo. De hecho, insiste en ver la metáfora como el "más poderoso (instrumento) que tenemos a nuestra disposición para transformar la realidad en un mundo adaptable a las intenciones y propósitos humanos" (Ankersmit, 2004: 12). Ambas posiciones son compartidas por Robert A. Rosenstone, cuyas reflexiones se centran en el ámbito de las representaciones históricas cinematográficas y, en concreto, en el carácter metafórico del lenguaje utilizado en este medio. En concreto, señala que el uso de la metáfora en el cine es uno de los caminos más utilizados para transmitir el pasado, dado que está cargada de significado, condición necesaria para conocer la realidad histórica representada (Rosenstone, 2012: 41).

5. La aplicación de estos postulados a un corpus concreto de trabajos de carácter audiovisual queda recogida en su tesis La metáfora visual incorporada: aplicación de la teoría integrada de la metáfora primaria a un corpus audiovisual, así como en posteriores trabajos de investigación. 
Metáforas en el cine - un recorrido por las representaciones del documental argentino sobre la crisis de 2001

\section{Metodología}

A continuación analizamos varias de las metáforas que el cine documental argentino ha utilizado para representar la crisis de 2001. Defendemos que estos instrumentos tienen un origen conceptual, a partir del cual se organiza la experiencia histórica. Por este motivo, nuestro punto de partida son los postulados de la lingüística cognitiva y, en concreto, de la Teoría Integrada de la Metáfora Primaria. Para ello, tendremos en cuenta la existencia de dos tipos de metáforas: por un lado las metáforas de correlación y de familiaridad que configuran la Teoría de la Metáfora Primaria de Grady y, por otro, las metáforas monomodales y multimodales, tipología recogida por Forceville. La selección de las mismas se ha llevado a cabo teniendo en cuenta el conjunto de procedimientos que intervienen en la realización de todo documental, que abarcan desde el encuadre hasta el montaje, pasando por la puesta en escena.

La Teoría Integrada de la Metáfora Primaria considera esta figura como la experimentación de una cosa en términos de otra. En ella se distinguen dos elementos: el dominio origen y el dominio destino. El primero es el interior de la metáfora, el mecanismo que presta sus conceptos. El segundo es el dispositivo que los recibe. Grady clasifica estas metáforas en dos grandes tipos: de correlación y de familiaridad. En las metáforas de correlación -dentro de las cuales se encuentran las metáforas primarias- el dominio origen contiene una imagen que funciona como la representación cognitiva de experiencias sensoriales, siendo este universal y conteniendo un significado particular en nuestra interacción con el mundo. El dominio destino, por el contrario, carece de dicha imagen, ya que se trata de unidades cuyas funciones cognitivas son accesibles de manera consciente. En el lado opuesto se sitúan las metáforas de familiaridad, que se caracterizan por la proyección de una estructura de una imagen mental en otra. Finalmente, la clasificación metafórica de Forceville distingue entre metáforas modales y multimodales. El primer tipo recoge las metáforas que se manifiestan en una única modalidad de información, como las verbales, visuales o auditivas. Por su parte, las metáforas multimodales tienen lugar en varias modalidades de información, como son los casos de las audiovisuales o verbo-audiovisuales.

Los documentales analizados son Memoria del saqueo (2004), de Fernando Solanas; Caballos en la ciudad (2006), de Ana Gershenson; Mosconi. Abriendo los caminos de la resistencia y la dignidad ${ }^{6}$ (2011), de Lorena Riposati; y Vida en Falcon (2005), de Jorge Gaggero. La selección de los mismos, dentro del centenar de cintas documentales que abordaron explícitamente la

6. En adelante, Mosconi. 
crisis de 2001 entre 2002 y $2012^{7}$, responde a dos criterios. En primer lugar, hemos primado la extensión temática que el conjunto de estos trabajos abarca, ya que el rastreo de una década de producciones documentales permite abordar la construcción metafórica de este periodo del pasado reciente argentino desde una perspectiva amplia. Del mismo modo, hemos tenido en cuenta la relevancia de estos trabajos por encima de su representatividad, a través de distintos factores que hemos agrupado en torno a la difusión obtenida por estas películas (emisiones en televisión, paso por festivales de cine, estreno comercial, circuito de exhibición alternativo y/o reproducciones de Internet).

Así, el documental de Fernando Solanas fue presentado el 4 de febrero de 2004 en el Festival de Berlín. A este evento le siguieron, en los meses posteriores, participaciones en más de una veintena de festivales internacionales. El 18 de marzo de ese año la película se estrenó comercialmente en 11 salas de Argentina, permaneciendo en cartel en algunas hasta el 27 de mayo. Un periodo durante el cual fue vista por 53.710 espectadores, según la consultora Ultracine. En paralelo a este circuito comercial, la cinta fue exhibida en espacios alternativos, tanto en asambleas populares y centros culturales como en universidades. Dos años después, el 7 de septiembre de 2006, fue emitida en Canal 7, la televisión pública del país. Esta proyección se repitió, en el mismo medio, el 15 de mayo de 2007. Según la consultora Ibope, la primera emisión fue vista por 109.363 espectadores y, la segunda, por 156.786. En 2007 el documental también fue emitido en el canal de TDT Encuentro, que no ofrece datos de audiencia. La película está subida a YouTube y lleva contabilizadas más de 300.000 reproducciones.

Por su parte, el trabajo de Ana Gershenson tuvo su estreno comercial en los cines porteños Palais de Glace y Tita Merello, el 2 de noviembre de 2007. Permaneció en sus programaciones durante un mes. ${ }^{8}$ También fue emitida en Canal 7, el 27 de noviembre de 2008, registrando 129.687 espectadores, según Ibope. Por su parte, el canal público de TDT Incaa tv, que tampoco proporciona datos de audiencia, lo ha emitido en más de una veintena de ocasiones desde

7. Para llegar a esta cifra se consultaron las bases de datos online que conservan información sobre los documentales de producción argentina que analizan la crisis de 2001, como Internet Movie Data Base (IMDb), de ámbito mundial; y cinenacional.com, focalizada en la cinematografía argentina. Además, se tuvieron en cuenta los trabajos financiados por el Estado argentino a través del Instituto Nacional de las Artes Audiovisuales de Argentina (INCAA), que publica un listado anual con las películas que reciben ayuda de este organismo; y los catálogos de las producciones de las asociaciones de carácter nacional de documentalistas argentinos. Estas son: Documentalistas Argentinos (DOCA), Realizadores de Documentales Integrales (RDI), Directores de Documentales (DOCU-DAC), Proyecto de Cine Independiente (PCI), Asociación de Documentalistas y Productores Independientes (ADN) y Directores Independientes de Cine (DIC). Del mismo modo, también se listaron las producciones de los realizadores que cuentan con página web.

8. Ni la consultora Ibope ni uno de los productores de la película Mariano Zukelberg confirman a la autora de este artículo este dato. 
Metáforas en el cine - un recorrido por las representaciones del documental argentino sobre la crisis de 2001

su puesta en marcha en 2011. Anteriormente había sido proyectada en la Berlinale y en otros festivales internacionales, como el Festival Internacional de Cine Independiente (Bafici), el Festival Internacional de Cine de La Habana, el Festival de Cine de Toulouse o el Festival de Cine documental de Barcelona. En cuanto a su circuito de exhibición alternativo, la cinta fue presentada en distintos ciclos de cine de organismos culturales de la ciudad de Buenos Aires.

En lo que respecta a la cinta de Lorena Riposati, esta fue estrenada comercialmente el 18 de agosto de 2011 en los cines Cosmos y Gaumont de Buenos Aires. En ambos espacios la película fue exhibida durante dos semanas, hasta el 29 de agosto. Durante este periodo fue vista por 487 espectadores, según Ultracine. Un año más tarde, en 2012, fue emitida siete veces en el canal público de TDT Incaa tv. En paralelo, el documental ha formado parte de la exhibición alternativa argentina, siendo proyectado tanto en jornadas de cine de instituciones culturales del país como en festivales de cine nacionales, especialmente de carácter político.

Por último, el documental dirigido por Jorge Gaggero se estrenó comercialmente el 2 de noviembre de 2005. Fue exhibida en los cines Cosmos y Malba hasta el 28 de diciembre de ese año. En esas semanas la película fue vista por 3.500 espectadores, según el director del documental. El 7 de diciembre de 2006 la película se emitió en Canal 7 y fue vista por 128.720 espectadores. En lo que respecta a los festivales de cine que recorrió, entre los mismos destacan el Bafici de 2005 y las ediciones de los festivales de cine de ese año de Biarritz, Viena, París y Londres. También generó un circuito propio de difusión alternativa, siendo sobre todo proyectada en ciclos de cine retrospectivos sobre la crisis de 2001.

La presencia de metáforas en estos cuatro documentales es desigual. De hecho, existen casos donde esta figura cuenta con un peso importante, tanto por su carácter cuantitativo y repetitivo, como por su diversidad semántica. Por el contrario, las metáforas son escasas, aunque no por ello poco importantes a nivel interpretativo, en otros ejemplos. Dado el desequilibro, y porque incluir las explicaciones de todas las metáforas existentes en las cuatro cintas superaría la extensión máxima fijada para su publicación, en este texto se ha optado por mostrar las figuras que sintetizan con mayor precisión la construcción de la crisis argentina de 2001. Esta diferencia explica, por tanto, porqué se reproduce un mayor detalle de análisis en unos documentales y menor en otros. 


\section{Resultados}

\section{Memoria del saqueo}

Este ensayo documental reflexiona en torno a las causas y consecuencias de la crisis de 2001. En él, la presencia de metáforas es abultada y reiterada, por lo que aquí nos limitaremos a analizar las más significativas, que se proyectan a través de distintos procedimientos de realización documental, como el montaje o la puesta en escena. Como hemos podido comprobar en el ejemplo con el que iniciábamos este artículo, las metáforas construyen, a través de oposiciones, una relación de causalidad, y connotan en distintas direcciones a los responsables y a las víctimas de la crisis.

En este sentido, el documental señala que los culpables de la crisis fueron el poder político argentino, el poder económico internacional y, en menor medida, la dirigencia sindical y el estamento judicial que lideraron el país entre 1976 y 2001. La metonimia "El lugar por la institución" representa tales entidades, a través de la proyección de imágenes de edificios del centro económico y financiero de Buenos Aires, de la Casa Rosada, de varios ministerios y de la sede de la Corte Suprema de Justicia. Las mismas también son representadas con metáforas ontológicas de personificación, que quedan recogidas en fotografías e imágenes de archivo de las personas responsables de la gestión de tales instituciones durante dicho periodo histórico.

Las metáforas de las que el documental se vale para construir el poder económico inciden tanto en el perfil de estas instituciones como en las acciones que estas llevaron a cabo durante el neoliberalismo. Así, la metáfora visual de correlación "Las relaciones son recintos", que se origina por la ubicación en un mismo espacio de entidades que interaccionan entre sí, utiliza el movimiento circular de la cámara sobre una plaza en la que se sitúan el Banco Nacional de la Provincia de Buenos Aires y el City Bank para trasladar al espectador uno de los pilares del modelo neoliberal y sus consecuencias: la apertura de la economía argentina hacia el exterior y el imparable aumento de la deuda externa que la decisión generó, la cual funcionó como leit motiv de la crisis. Esta metáfora también corresponsabiliza al Estado argentino del empeoramiento de la situación económica del país. Así, la presencia del Banco Nacional de la Provincia de Buenos Aires en la imagen recibe una crítica implícita, ya que de la misma se desprende que el poder político local argentino actuó de manera subordinada a los vaivenes del capitalismo financiero internacional, sin ejercer un control sobre él. En paralelo, otro de los pilares del mencionado modelo económico queda patente en la metáfora visual de correlación "Caer es morir". Un recurso con el que se denuncia, a través de la inclusión de la 
Metáforas en el cine - un recorrido por las representaciones del documental argentino sobre la crisis de 2001

imagen del derrumbe de un edificio y su encadenamiento con otra instantánea que proyecta el logotipo de YPF, la muerte simbólica de esta empresa, privatizada en 1991 y, por extensión, el deceso del patrimonio público argentino, que en un importante porcentaje pasó a ser gestionado por grandes corporaciones multinacionales. Sin embargo, donde el poder económico queda más críticamente reflejado es en las metáforas visuales de correlación "Similitud es proximidad" y "Similitud es alienación". La motivación de la primera metáfora es la tendencia que tenemos a pensar similares aquellas entidades que se encuentran juntas físicamente; la segunda, la correlación que establecemos al observar que objetos similares se orientan del mismo modo precisamente porque son parecidos. Para materializarlas, el relato yuxtapone dos planos en movimiento, donde se representan la conquista de América y la actual city porteña, a través del barrido de un cuadro y una panorámica en los que predominan los mismos colores. Esta estrategia discursiva define las acciones de los grupos económicos internacionales entre 1976 y 2001, pero sobre todo entre 1989 y 1999, periodo en el que se produjeron un mayor número de privatizaciones, denunciado a su vez un comportamiento neocolonialista por parte de las mencionadas corporaciones (imágenes 3 y 4).
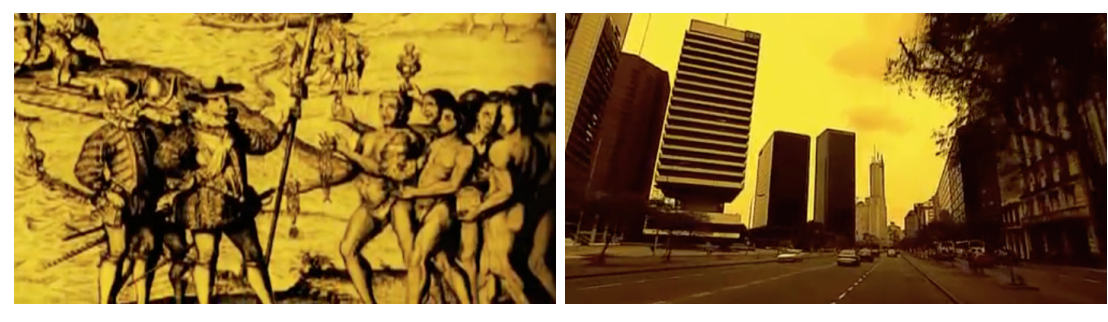

Imágenes 3 y 4 .

El poder político que permitió este comportamiento también es representado metafóricamente. En primer lugar, a partir de las metáforas visuales de correlación "Las circunstancias son clima", "Lo malo es oscuro" y la metáfora audiovisual de correlación "La compulsión es una fuerza irresistible". La primera fórmula tiene como origen la correlación entre el tiempo atmosférico y el estado de ánimo, ya sea de un sujeto o de una sociedad en su conjunto. En este documental se utiliza en dos intertítulos al inicio de la narración cuyos textos, impresos sobre sendas panorámicas de Buenos Aires bajo un cielo encapotado, nos advierten del resultado electoral de las elecciones de octubre de 2001. Unas instantáneas que asocian las condiciones climáticas adversas con la política llevada a cabo por los gobiernos neoliberales, cuya adscripción ideológica es heterogénea y abarca tanto al Peronismo como al Radicalismo 
o la alianza entre distintas formaciones políticas. En concreto, la dimensión política de la crisis se vincula a las demandas de cambio ejercidas por la ciudadanía argentina a través del voto y el surgimiento de resistencias populares. Unas peticiones que, critica la metáfora, fueron desoídas por parte de los representantes legislativos surgidos de las urnas, que continuaron aplicando políticas neoliberales contrarias a los intereses de la sociedad civil argentina. La segunda metáfora es producto de la relación que establecemos entre la oscuridad y el peligro. En este caso es aplicada para representar, especialmente, a los ex presidentes de la República Carlos Menem y Fernando de la Rúa y al ex ministro de Economía de ambos, Domingo Cavallo. Para ello, se utilizan fotografías de sus rostros en blanco y negro, dispositivos que los perfilan negativamente, no solo como responsables de la crisis económica, sino en tanto depositarios de la crisis de representación que atravesaba la ciudadanía de este país, que se materializó en una falta de confianza generalizada hacia las instituciones democráticas (Sidicaro, 2002), así como en el surgimiento de nuevos movimientos sociales (Svampa, 2003), que ejercieron de actores sustitutos del Estado, dada la ausencia tanto de una política pública que apaciguara los efectos negativos en la economía como de un asistencialismo estatal activo hacia los estratos más vulnerables. La tercera metáfora con la que se representa al poder político incide en este aspecto. La misma hace referencia a la correlación entre el movimiento de alguien y el carácter deliberado de sus acciones. Esta metáfora se materializa con la proyección de la canción Levantamanos, que destaca por su paródica letra ${ }^{9}$, sobre imágenes del Congreso de la Nación en el transcurso de una votación ordinaria. Una crítica, a través de la combinación del contenido de la canción, el ritmo lento de la melodía y las imágenes, hacia el rol pasivo ejercido conscientemente por este estrato del poder político y, por extensión, desde el Estado.

Las metáforas expuestas hasta el momento nos han servido para conocer los mecanismos de representación que este documental utiliza para construir a los responsables de la crisis de 2001. ¿Sucede lo mismo con las víctimas? En parte, sí. La proyección de estas también se lleva a cabo a partir de metáforas ontológicas de personificación, además de incorporando de la metonimia "El lugar por el acontecimiento", lo que da lugar a la creación de nuevas metáforas. Es el caso de "Lo malo es oscuro" y "Las circunstancias son clima", metáforas visuales de correlación que representan las consecuencias económicas negativas del neoliberalismo. Ello es perceptible en el espacio que explica el fenómeno de la desindustrialización y el adelgazamiento del tejido productivo del

9. Esta apela al rol de los representantes de la ciudadanía y dice lo siguiente: "Somos levantamanos, consecuentes, comedidos. Votamos con ojos cerrados, lo que nos manda el partido (vis). Y al votante traicionamos, a pesar de los silbidos". 
Metáforas en el cine - un recorrido por las representaciones del documental argentino sobre la crisis de 2001

país que trajo consigo la apertura de la economía desarrollada en paralelo a la última dictadura cívico-militar y, especialmente, la convertibilidad, ${ }^{10}$ medida estrella de la primera administración de Carlos Menem. Así, el relato proyecta largos travellings y panorámicas de calles repletas de locales vacíos, de interiores de fábricas abandonadas $\mathrm{y}$, fundamentalmente, del puerto de Buenos Aires, que presenta una actividad muy limitada. Tales metáforas se generan a través de la puesta en escena, pues las situaciones enunciadas se registran en entornos con unas condiciones climatológicas adversas y escasa proyección de luz, vinculando la crisis con las malas épocas y el peligro. Unas estrategias que también se utilizan para representar la pobreza y la desnutrición, acentuadas por la crisis. En estos casos, el documental proyecta varias secuencias en una villa de La Matanza, inundada por las lluvias, donde el mal tiempo refleja la situación de los habitantes de este lugar, también adversa.

Estas últimas metáforas podrían hacernos creer que el documental se vale de idénticas estrategias para representar a los responsables y a las víctimas de la crisis. Sin embargo, estos se configuran a partir de una relación de oposición, por lo que el relato proyecta nuevas metáforas que acentúan tal diferenciación. "Existir es ser visible" y "Luz es vida" funcionan en este sentido. La primera establece una correlación entre la conciencia que tenemos sobre determinados sujetos y su presencia en nuestro campo de visión. Así, el documental se encarga de traernos al primer plano, a través de un zoom largo de alejamiento aplicado sobre un vertedero, las bolsas de pobreza existentes en la provincia de Tucumán. Esta condición se ve reforzada por la segunda metáfora, que se constata en el momento elegido para tomar las imágenes, a plena luz del día, denunciando con ellas que la pobreza en el país es un problema latente (imagen 5).

En oposición a este fenómeno se generaron nuevos movimientos sociales, aparición que subraya la dimensión política y social de la crisis de 2001. Es el caso de los piqueteros, que emergieron como oposición al incremento del desempleo en el país. Esta resistencia se representa en el documental a partir de la metáfora visual de correlación "Lo bueno es arriba", que se genera otorgando a un sujeto o a un objeto una orientación física elevada. En este caso la metáfora surge de la aplicación en la imagen de un plano general contrapicado, que personifica al movimiento de desocupados en las figuras de tres ex trabajadores de YPF en Cutral Co (provincia de Neuquén), localidad en la que surgió oficialmente el movimiento piquetero, pues fue donde tuvieron lugar los primeros cortes de ruta, seña de identidad de estas organizaciones. En

10. La convertibilidad se constituyó como el buque insignia de la política económica menemista y se desarrolló en torno a dos ejes: la paridad del peso argentino con el dólar y las privatizaciones de empresas de titularidad pública. Véase Roig, 2016. 
este sentido, el plano contrapicado utilizado en la cinta construye a los piqueteros como una opción política positiva y rompe con el estereotipo negativo construido en torno a esta figura (Settanni, 2006), pues el corte de ruta que los distingue es entendido como el signo canalizador de su identidad laboral sustituida (imagen 6).

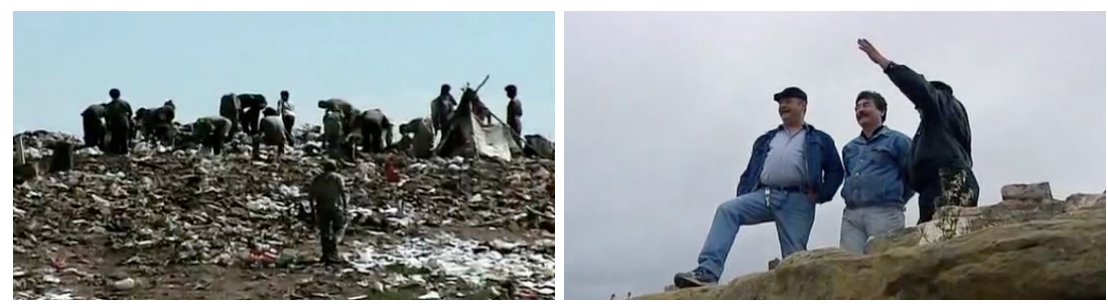

Imágenes 5 y 6 .

\section{Caballos en la ciudad}

El aumento del número de cartoneros que diariamente llegaban a Buenos Aires desde la periferia se convirtió en uno de los principales símbolos de la crisis de 2001. Acechados por la desocupación y las necesidades de subsistencia, estos ciudadanos personificaron, a través de su actividad recolectora de desechos, la decadencia del país. Una experiencia que recoge el documental dirigido por Ana Gershenson, que refleja las historias de vida de seis de estos trabajadores del cartón, donde también hay espacio para las representaciones metafóricas.

Estas son proyectadas desde los títulos de crédito que dan inicio al relato. El recurso se construye, a través de la yuxtaposición y combinación de fotografías en detalle del trabajo de los cartoneros y de distintas obras de arte -la mayoría de las cuales de Antoni Tapies, pero también de El Bosco, Jean Claude \& Christo y Kurt Schwitters-, las metáforas visuales de correlación "Similitud es proximidad" y "Similitud es alienación". La primera se configura a partir de la yuxtaposición de planos, cercanía que asocia la actividad cartonera con la artística. La segunda surge de la agrupación de los elementos que contienen las imágenes, pues estas presentan características parecidas, como la forma, el color o los tejidos. Estas metáforas resultantes cumplen una doble función. Por un lado, refuerzan la vinculación entre ambas actividades, lo que impregna a la actividad cartonera de prácticas y contenidos propios del arte. Así, el recurso dignifica la figura de los sujetos que protagonizan la narración a la vez que defiende la realización de la actividad que les proporciona un sustento econó- 
Metáforas en el cine - un recorrido por las representaciones del documental argentino sobre la crisis de 2001

mico. De esta manera, de la metáfora se desprende que la figura del cartonero ha de ser entendida como sinónimo de trabajador y, la recogida de desechos que este lleva a cabo, como el mecanismo que le brinda la posibilidad de portar una identidad laboral restituida y lo aleja del estereotipo negativo construido en torno a él por otros medios de comunicación (Biancardi, 2007).

Sin embargo, algunos ejemplos connotan las imágenes de un significado añadido, lo que fomenta las advertencias hacia los espectadores. Es el caso de la asociación entre el plano que muestra la obra de El Bosco -un detalle de Las tentaciones de San Antonio, que reproduce los pies de un patinador sobre hielo, y la imagen siguiente, también los pies de un cartonero junto con las pezuñas de su yegua (imágenes 7 y 8). Para conocer el significado de la metáfora debemos acceder a la simbología de la obra de este artista. En ella, la presencia del hielo bajo los pies del patinador indica fragilidad, ya que este se encuentra sobre una superficie que "tiene falsa capacidad de sustentación", la cual puede romperse en cualquier momento (Peñalver, 1999: 141). Una condición de vulnerabilidad que se traslada a la imagen que representa al cartonero y que cobrará total sentido unas secuencias después, cuando conozcamos que los pies pertenecen a un niño que mantiene a su familia a través de esta actividad. De esta forma, la metáfora funciona como mecanismo de asociación, pero lo que es más importante: ejerce de crítica sobre la situación y futuro del sujeto representado.

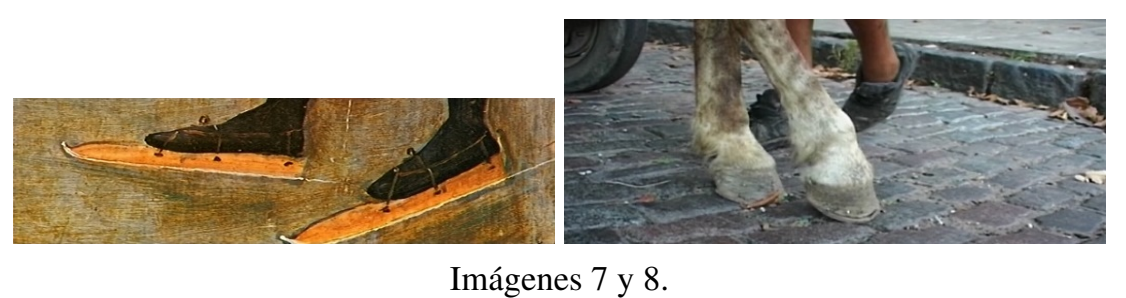

El desplazamiento de la periferia a la ciudad que llevan a cabo los cartoneros a diario, y que aparece reiteradamente en el documental, también se utiliza para representar metafóricamente la crisis a nivel social y económico. En primer lugar retratando su paisaje, cuya proyección genera la metonimia "El lugar por el acontecimiento". Caminos de barro, tejados de chapa, fábricas abandonadas, inactividad en el Riachuelo y hasta el hierro oxidado del Puente Uriburu son sus componentes, los cuales son subrayados a través de planos generales, primando el espacio sobre los sujetos. Unos elementos que definen el paisaje de la crisis, el momento contemporáneo a la elaboración del documental, pero que inevitablemente apelan a determinados momentos más boyantes 
del pasado de este país, como el primer Peronismo, cuando se construyó (Silvestri, 2004), y constatan la decrepitud generada por el ajuste neoliberal, ya que lo que en ese momento se encuentra abandonado y oxidado, otrora registró actividad y brillo (imagen 10).

Por otro lado, en este documental el perfil de estos sujetos del documental también se construye mediante metáforas. Para ello se echa mano de intertítulos, carteles que separan las historias de vida que conforman el relato. En los mismos aparece la metáfora visual de correlación "Periférico es poco importante", que asocia la posición geográfica de los cartoneros con la falta de acceso o control sobre los objetos o situaciones que se les presentan. La metáfora se materializa, a su vez, añadiendo la representación gráfica de su lugar de residencia, Lanús, que se encuentra alejado de la ciudad y separado por el Riachuelo, límite sociopolítico que constata la condición periférica de estos y, por tanto, su condición de ciudadanos poco importantes.

La figura de los cartoneros se construye, además, con las metáforas visuales de correlación "Estar controlado es abajo" e "Importancia es volumen". La primera se configura con el uso de un plano picado de los cartoneros desde el Puente Uriburu cuando estos acceden a Buenos Aires. El mecanismo les otorga una orientación espacial negativa, ya que esta señala de manera implícita la carencia de control que tienen sobre su vida (imagen 10). Idéntica condición constata la segunda metáfora, en las mismas imágenes, que asocia el tamaño de los sujetos y el valor que supone su interacción con ellos, en este caso insignificante, ya que aparecen reducidos.
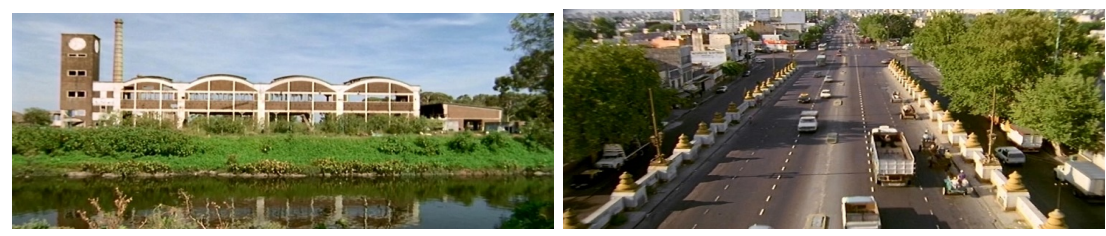

Imágenes 9 y 10.

\section{Mosconi}

Las resistencias populares que surgieron en oposición a las políticas neoliberales en el movimiento piquetero a uno de sus principales exponentes. El mismo nació durante la década de los años 90, consecuencia de la escalada del desempleo en el país, especialmente en el sector público y entre los ex trabajadores de empresas que habían sido privatizadas los años anteriores, y tuvo en el corte de ruta su principal rasgo identitario. La agrupación constituida en 
Metáforas en el cine - un recorrido por las representaciones del documental argentino sobre la crisis de 2001

Mosconi (Salta) fue una de las más tempranas y significativas, experiencia que expone este documental. En este trabajo las metáforas definen el espacio de la crisis, perfilan a sus sujetos y reconstruyen históricamente el recorrido del movimiento piquetero de esta localidad: la denominada Unión de Trabajadores Desocupados (UTD).

Al igual que sucedía en los documentales analizados, este trabajo también se inicia utilizando metáforas. En concreto, asistimos a la proyección del paisaje de la crisis, aunque en esta ocasión tal espacio está constituido por distintos elementos. Si en el documental de Ana Gersenshon la metonimia "El lugar por el acontecimiento" se proyectaba a partir de la inactividad del Riachuelo y las fábricas abandonadas o el hierro oxidado de los puentes nos informaban de tal contexto, en esta cinta accedemos a un paisaje diferente. El mismo se encuentra configurado, en primer término, por el aislamiento de la localidad, que se materializa a través del registro de la cámara de escasos comercios cerrados y viviendas. Sin embargo, el principal rasgo de tal paisaje está unido a la desocupación y será proyectado en las secuencias posteriores, cuando la cámara se desplace al galpón de la UTD de Mosconi, en el que se encuentran numerosos hombres jóvenes, sin actividad laboral aparente. Este paisaje de la crisis será completado con los testimonios de mujeres desocupadas, registrados en la estación de ferrocarril del municipio, mientras recorren a pie el camino paralelo a las vías. Un espacio fantasma que se distingue por su alto nivel de abandono, donde la única presencia que existe es la de un tren abandonado sobre unos raíles oxidados y el ganado que pasta sobre la hierba surgida consecuencia de tal inactividad.

Por su parte, la caracterización de los sujetos de la crisis, los trabajadores desocupados protagonistas del documental y los políticos responsables de tal coyuntura, también se representa a través de metáforas. En concreto, este trabajo se vale de la metáfora visual de correlación "El cuerpo es un contenedor" para representarlos. La misma se plantea a través del montaje con imágenes de archivo de 1989, año en el que el peronista Carlos Menem inicia su primer gobierno y fecha que da comienzo al periodo de mayor intensificación de la aplicación de medidas neoliberales en Argentina. En concreto, el documental proyecta al entonces presidente anunciando la privatización de las principales empresas públicas del país y, en el plano yuxtapuesto, muestra el rostro uno de los desocupados que protagonizan el documental. La metáfora refleja, a partir del rostro del piquetero, los efectos del citado modelo político y económico intensificado por Menem y, concretamente, la privatización de empresas como YPF, donde trabajaba el afectado. A su vez, funciona como instrumento de crítica hacia las palabras del político, pues el montaje utilizado desdice iróni- 
camente sus palabras. En ellas, el político se jactaba de que la privatización traería consigo un mayor bienestar para la ciudadanía. Por el contrario, las imágenes subrayan la situación extrema de exclusión que atraviesa el piquetero, en tanto representante de los depositarios de las consecuencias negativas de dicha decisión (imágenes 11 y 12).
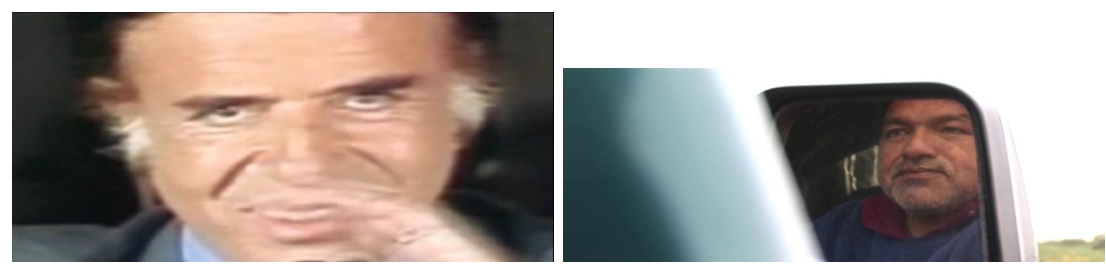

Imágenes 11 y 12.

Por último, la construcción del movimiento de desocupados también se construye a través de varias metáforas. Esta representación, sus connotaciones económicas y políticas, se proyectan a través de cuatro separadores que, a modo de animaciones, introducen las distintas etapas históricas de la localidad y la evolución de la organización. La primera de ellas expone el hallazgo de yacimientos petrolíferos en el lugar, el nacimiento de YPF y los beneficios que esta empresa generó entre los habitantes de la localidad, mejorando la misma a través de la construcción de infraestructuras y viviendas confortables. La misma se representa a través de la metáfora visual de correlación "Lo bueno es luminoso", pues las animaciones se reproducen sobre fondos blancos a los que se ha aplicado un filtro de luz. A continuación tiene lugar la etapa privatizadora, que se representa bajo la metáfora "La naturaleza de una entidad es su forma", en alusión al cambio de propiedad de YPF y la llegada de capital privado a la localidad. En este caso, los grupos económicos que comenzaron a gestionar los recursos naturales de la provincia son representados como aves de rapiña de color negro (imagen 13) cuyo paso por la localidad solo deja devastación. La tercera animación representa el nacimiento del movimiento piquetero, consecuencia de la desocupación que ha crecido en la localidad por la privatización del petróleo, y la aparición de los primeros cortes de ruta. Unas animaciones que proyectan las metáforas "Lo malo es oscuro" y "El fuego es vida", en alusión a los primeros atisbos de organización de los desocupados de la localidad, que quedan reflejados en el protagonismo del negro de las imágenes y en la aparición de los primeros cortes de ruta a través del fuego, sinónimo de la vida que define al movimiento (imagen 14). La cuarta animación representa la empatía e identificación mostradas hacia los piqueteros por los vecinos del municipio, a través de las puebladas que se desarrollaron entre 
Metáforas en el cine - un recorrido por las representaciones del documental argentino sobre la crisis de 2001

1997 y 2001 consecuencia de la represión estatal que los desocupados recibieron. Esta etapa queda reflejada bajo la metáfora "Lo bueno es luminoso", pues al recuperar las imágenes el dinamismo, el cambio se asocia a institucionalización del movimiento piquetero y a la solidaridad que este generó entre la población, siendo percibido como algo positivo.

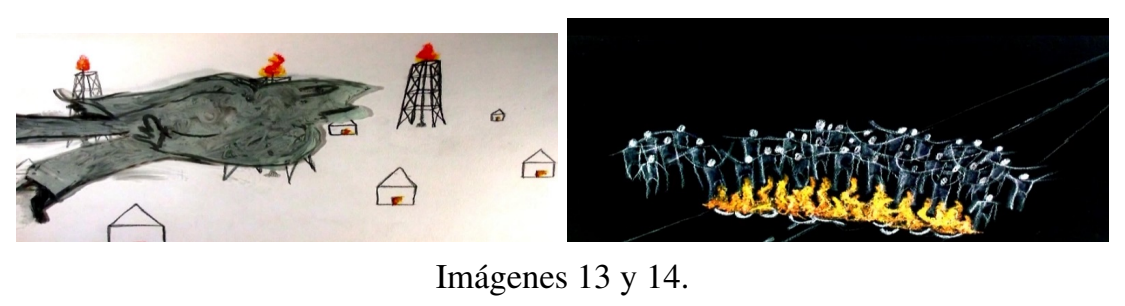

\section{Vida en Falcon}

El recorrido por las representaciones de la crisis de 2001 en el cine documental argentino finaliza el documental dirigido por Jorge Gaggero. Hasta el momento, las metáforas que hemos encontrado en el camino han construido este periodo histórico en términos de oposición y han perfilado los sujetos que la experimentaron, tanto en lo que respecta a los responsables de la misma como a aquellos en los que recayeron sus consecuencias. Hincapié especial es el que han hecho en los movimientos sociales de resistencia al neoliberalismo. Pero, ¿Qué dicen los relatos sobre la crisis de los otros sujetos, aquellos que se vieron afectados por la misma y que no se organizaron a través de ninguna entidad? Este trabajo se encarga de argumentar sobre tales experiencias.

En concreto, el documental registra los cambios que la crisis de 2001 generó en la clase media argentina. Lo hace a través de dos historias concretas: la de Luis y Orlando, que viven en un Ford Falcon. El primero acaba de adquirir el coche y se ve obligado a hacer de él su lugar de residencia, tras empeorar su situación económica, de la que el espectador poca información más llega a conocer. El segundo ha institucionalizado esta situación, pues reside en el automóvil desde hace varios años, tras perder la casa en la que vivía y el taxi en el que trabajaba. Los dos personajes representan la movilidad descendente que la crisis provocó en la clase media de este país, la cual vio adelgazar su poder adquisitivo y modificar su estatus social. Movilidad descendente que el documental registra, tanto física como simbólicamente. La primera característica queda patente a través de la vida nómada de los protagonistas del documental, que han pasado de residir en lugares cómodos y confortables a hacerlo en coches destartalados, en los que duermen, comen y se relacionan con el resto de 
los vecinos del barrio. La segunda se confirma a partir de las connotaciones que van adheridas al vehículo que poseen. Emblema del capitalismo y consumismo, pero sobre todo signo de progreso, desarrollo y bienestar, el Ford Falcon se adscribe a un periodo histórico concreto la historia de este país: los años 70, fecha en que se inicia el modelo neoliberal. Una correlación que impregnaba a este momento del pasado y a los propietarios de este coche de tales rasgos positivos. Asimismo, no hay que olvidar una tercera connotación asociada a este vehículo, que resulta ineludible en el imaginario social argentino. La misma hace referencia al rol represivo del Estado durante la última dictadura cívico-militar, pues el Ford Falcon era el vehículo prototipo utilizado por las fuerzas de seguridad del país para materializar detenciones arbitrarias y desapariciones forzosas.

En este sentido, la metonimia "El objeto por el usuario" representa, a través del Ford Falcon de los protagonistas, los cambios que la crisis provocó en la clase media argentina y, a su vez, expone el devenir histórico de este estrato social, señalando directamente las consecuencias sociales y económicas que el neoliberalismo generó en el país. Para ello, la cinta refuerza su argumento utilizando un anuncio de los años 70 como dispositivo de apertura y cierre de la narración, con el que quedan cuestionados los beneficios del coche, que como decíamos pasó de ser el signo de un prometido progreso económico (además de una represión estatal materializada), a convertirse en objeto de contención de los sujetos afectados social y económicamente por las consecuencias negativas del neoliberalismo (imágenes 15 y 16).

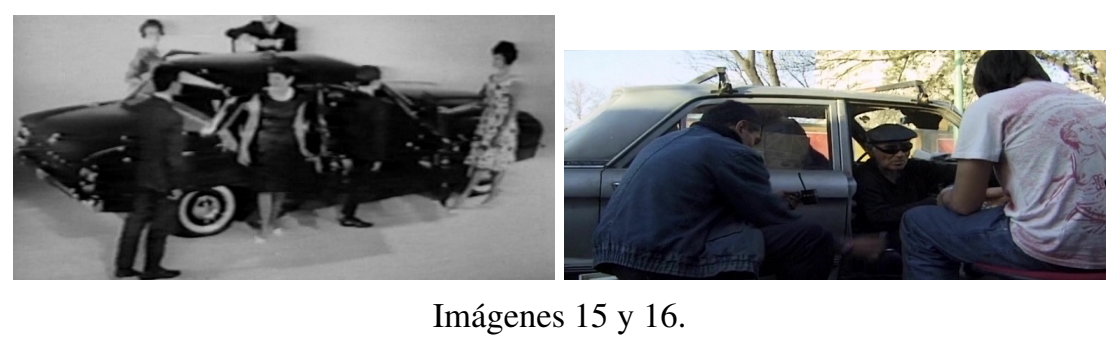

\section{Conclusiones}

Las metáforas aquí analizadas nos han resultado muy útiles para conocer qué significados se transfieren entre los dominios origen y destino que configuran sus estructuras, dejándonos algunas conclusiones en torno a la crisis de 2001. En primer lugar, es reseñable la notable presencia global de estas figuras en los trabajos estudiados, a pesar de la consideración de este género 
Metáforas en el cine - un recorrido por las representaciones del documental argentino sobre la crisis de 2001

cinematográfico como un modo de representación de la realidad histórica no metafórico. En este sentido, y como segunda conclusión, destacamos la construcción en términos de oposición que las metáforas hacen de esta porción del pasado, focalizando a sus responsables y a sus víctimas y posicionando los relatos a favor de estas últimas. Por último, también queremos subrayar la comparación, implícita y explícita, que las metáforas realizan de la crisis de 2001 con otros momentos de la historia argentina, espacios temporales que se configuran tanto como modelos de imitación como de rechazo.

En lo que respecta a la presencia de estos dispositivos en los documentales estudiados, a lo largo de las páginas que constituyen este texto han aparecido un total de 30 metáforas, tanto visuales como audiovisuales, todas ellas de correlación. Asimismo, la mayoría se han configurado a través del montaje como procedimiento de realización documental utilizado, aunque la puesta en escena y el encuadre también han sido determinantes para materializarlas. Unos resultados que refuerzan la postura de White, Ankersmit y Rosenstone de considerar la metáfora como un camino legítimo de representación del pasado.

Sin embargo, para verificar este mecanismo es necesario desglosar la información que proyectan sus dominios. Así, las metáforas insertadas en los documentales analizados han construido la crisis de 2001 como una consecuencia de las políticas neoliberales aplicadas en Argentina en un periodo amplio, que se extendió entre la última dictadura militar (1976-1983) y el estallido popular de diciembre de 2001. Esta dilatación temporal del neoliberalismo es proyectada como efecto de las acciones llevadas a cabo por un conjunto de elites que, en calidad de responsables de la crisis, son construidas negativamente. En el ámbito económico, la crisis es representada como el resultado de la suma de un conjunto de factores, entre los que destaca la apertura exterior de la economía argentina, decisión que derivó, entre otros aspectos, en unos importantes índices de desindustrialización, en la caída de la actividad comercial, en un incremento del desempleo y de la pobreza, en una mayor vulnerabilidad del sistema financiero y en el auge de la deuda externa del país, que se tornó insostenible y funcionó como leit motiv de la coyuntura de crisis. Estos indicadores trajeron consigo un agravamiento de la dependencia internacional del país, subordinación que es achacada a las maniobras del mencionado poder económico. Este, compuesto por grandes corporaciones y financieras, es acusado de desarrollar un comportamiento neocolonialista y de disolver el patrimonio público del país en beneficio propio. Tal vaciamiento de la riqueza argentina es denunciado por las metáforas a través de la concepción del poder económico como el principal beneficiado de la crisis de 2001, pues las corporaciones internacionales se adjudicaron las licencias y la gestión de un alto número de empresas públicas 
de capital argentino vía privatizaciones. Un cambio en los titulares de estas organizaciones que, según se denuncia, se fraguó gracias a la connivencia con el poder político local argentino. De hecho, se critica que el Estado no ejerciera una supervisión y un control de estas prácticas, y que tampoco actuara en defensa de los intereses de la ciudadanía.

En cuanto a esta dimensión política, los orígenes de la crisis de 2001 se circunscriben al gobierno de facto que surgió tras el golpe de Estado de 1976, que sentaron las bases del neoliberalismo en Argentina; así como a las gestiones de los gobiernos que se sucedieron entre 1983 y 2001, que continuaron aplicando estas medidas. La adscripción ideológica y partidaria de las administraciones que se connotan negativamente son heterogéneas, ya que abarcan tanto a la Unión Cívica Radical (1983-1989), como al Partido Justicialista (1989-1999) y a las alianzas entre distintas fuerzas políticas (1999-2001). No obstante, en las metáforas se enfatizan críticamente las consecuencias negativas de las dos administraciones lideradas por Carlos Menem, cuando el modelo neoliberal fue aplicado con mayor intensidad y cuando tuvo lugar un importante giro conservador por parte del Peronismo. De igual modo, se produce una personificación de los responsables políticos de la crisis, cuyos nombres se repiten en las distintas metáforas analizadas, siendo el citado Carlos Menem, así como Fernando de la Rúa y Domingo Cavallo, los que más aparecen. A ellos no solo se les acusa de aplicar las políticas neoliberales en Argentina y de actuar como subordinados de las corporaciones internacionales en su propio beneficio, traicionando a la sociedad civil. También son mostrados como los depositarios de la crisis de representación que esta atravesaba, cuyas demandas de cambio se materializaron a través del voto, primero, y con el estallido popular de diciembre de 2001, después. Unas denuncias que se llevan a cabo tanto de manera irónica como explícitamente.

En el lado opuesto se sitúan los depositarios de las consecuencias de la crisis, las víctimas del neoliberalismo. Estas representaciones metafóricas se caracterizan por subrayar la condición de desocupados, empobrecidos y excluidos por parte del sistema de los sujetos que protagonizan los documentales y se esfuerzan en proyectarlos como personajes subordinados a las pautas que les marcan el Estado y el mercado. Unas construcciones, no obstante, que hacen hincapié en mostrar la desigualdad que padecen los protagonistas en tanto circunstancia producto de la coyuntura de crisis, no como un rasgo inexorable a su condición de sujetos sociales y políticos. Para ello, se opta por darles una visibilidad y por posicionarse a favor de las acciones que llevan a cabo, proyectando las resistencias populares que integran. En el caso de los piqueteros, se transmite la idea de que las organizaciones de desocupados funcionan 
Metáforas en el cine - un recorrido por las representaciones del documental argentino sobre la crisis de 2001

como dispositivos de sustitución de la identidad laboral perdida de los protagonistas de los documentales, pues en las cintas aparecen portando una nueva identidad, la piquetera, que tiene en el corte de ruta su principal rasgo identificativo. Por su parte, la actividad al margen del Estado que desarrollan los cartoneros también es aplaudida en las metáforas analizadas. De hecho, estas no solo coinciden en mostrar tales proyectos como sinónimo de trabajo e inclusión en la sociedad, sino que también se esfuerzan en trasladar la idea de que recoger desechos en la ciudad fomenta la configuración de una identidad laboral restituida de los cartoneros, ya que para ellos supone una alternativa al desempleo, a la falta de ingresos y a la desigualdad.

En paralelo, las metáforas utilizadas funcionan como herramientas para comparar la crisis con otros periodos del pasado argentino. En esta línea, han sido evidentes los ejemplos que se inclinan en enfatizar los éxitos del modelo económico basado en el intervencionismo estatal, desarrollado en la primera mitad del siglo XX y continuado hasta la apertura de la economía que trajo consigo la última dictadura cívico-militar (1976-1983) y, con ella, el neoliberalismo. Esta opción es muy explícita en las metáforas que proyectan la existencia de un clima de bienestar mientras que YPF fue una empresa pública, pues tal condición supuso importantes ventajas para los habitantes de las localidades en las que se ubicaban sus plantas, política que las metáforas analizadas defienden y apuntan como estrategia a seguir. Por el contrario, el neoliberalismo es el modelo a rechazar. Esta postura queda reflejada metonímicamente a través de la crítica que se hace de la movilidad descendente de la clase media del país registrada durante el periodo en que se aplicó, así como en el negativo devenir de los integrantes de las clases populares. Este paralelismo es muy evidente en la representación del puente Uriburu. Una edificación, levantada durante el primer Peronismo, que traslada al espectador a aquellos tiempos, vinculados con bonanza y el desarrollo argentinos, a la vez que contrapone el periodo histórico en el que se construyó el puente con el tiempo presente del relato, señalándolo implícitamente como modelo a seguir.

Definiciones, oposiciones, comparaciones, advertencias. Lejos de presentarse como un adorno, las metáforas analizadas a lo largo de estas páginas han dejado claro que son un dispositivo a través del cual organizamos nuestro conocimiento sobre el pasado. Motivo por el que deben ser tenidas en cuenta a la hora de enfrentarnos a los relatos históricos.

\section{Referencias bibliográficas}

Ankersmit, F. (2004). Historia y tropología. Ascenso y caída de la metáfora. México: Fondo de Cultura Económica. 
Biancardi, M. S. (2007). Representaciones sociales de los actores ligados a la basura de la ciudad de Buenos Aires en Clarín. Revista del Centro de Cultural de la Cooperación, (7). Disponible en: http://goo.gl/RYG5FA

Escandell Vidal, M. V. (2006). Introducción a la pragmática. Madrid: Ariel.

Lakoff, G. \& Mark, J. (1990). Metáforas de la vida cotidiana Madrid: Cátedra.

Lakoff, G. \& Johnson, M. (1996). Philosophy in the flesh. The embodied mind and its Challenge to western thought. Nueva York: Basic books.

Ortiz Díaz-Guerra, M. J. (2009). La metáfora visual incorporada: aplicación de la teoría integrada de la metáfora primaria a un corpus audiovisual. Alicante: Universidad de Alicante.

Peñalver, L. (1999). Los monstruos de El Bosco. Valladolid: Junta de Castilla y León.

Ricoeur, P. (2007). Tiempo y narración I. Configuración del tiempo en el relato histórico. México: Siglo XXI editores.

Roig, A. (2016). La moneda imposible. La convertibilidad argentina de 1991. México: Fondo de Cultura Económica.

Rosenstone, R. A. (2012). Film on history, history on film. Essex: Longman.

Settanni, S. (2006). La representación acerca de los piqueteros construida por La Nación, Cutral Co/Plaza Huincul 1996-97-Buenos Aires, 2004. Cuestión, (12). Disponible en: http://goo.gl/GN0Omd

Sidicaro, R. (2002). Las desintegraciones institucionales argentinas y sus consecuencias sociales. Punto de vista, (72): 37-41.

Silvestri, G. (2003). El color del río. Historia cultural del paisaje del Riachuelo. Buenos Aires: Universidad Nacional de Quilmes/Prometeo.

Svampa, M. \& Pereira, S. (2003). Entre la ruta y el barrio. La experiencia de las organizaciones piqueteras. Buenos Aires: Editorial Paidós.

White, H. (2003). El texto histórico como artefacto literario y otros escritos. Buenos Aires: Paidós. 